\title{
An Investigation on the Morphological and Mineralogical Characteristics of Posidonius Floor Fractured Lunar Impact Crater Using Lunar Remote Sensing Data
}

\author{
Imen Ben Salem ${ }^{1,+}$, Manish Sharma ${ }^{1, *}+\mathbb{D}^{\mathbb{D}}$, P. R. Kumaresan ${ }^{1,2} \mathbb{D}$, A. Karthi ${ }^{1,3}$, Fares M. Howari ${ }^{1} \mathbb{D}$, \\ Yousef Nazzal $^{1}$ (D) and Cijo M. Xavier ${ }^{1}$ (D)
}

1 College of Natural and Health Sciences, Zayed University, Abu Dhabi P.O. Box 144534, United Arab Emirates; imen.bensalem@zu.ac.ae (I.B.S.); prkumaresan@bdu.ac.in (P.R.K.); karthiatkj@gmail.com (A.K.); fares.howari@zu.ac.ae (F.M.H.); yousef.nazzal@zu.ac.ae (Y.N.); cijo.xavier@zu.ac.ae (C.M.X.)

2 Department of Remote Sensing, Khajamalai Campus, Bharathidasan University, Tiruchirappalli 620023, Tamil Nadu, India

3 Centre for Applied Geology, The Gandhigram Rural Institute, Deemed to be University, Gandhigram, Dindigul 624302, Tamil Nadu, India

* Correspondence: manish.sharma@zu.ac.ae; Tel.: +971-25-993-804

+ These authors contributed equally to this work.

\section{check for}

updates

Citation: Salem, I.B.; Sharma, M.; Kumaresan, P.R.; Karthi, A.; Howari, F.M.; Nazzal, Y.; Xavier, C.M. An Investigation on the Morphological and Mineralogical Characteristics of Posidonius Floor Fractured Lunar Impact Crater Using Lunar Remote Sensing Data. Remote Sens. 2022, 14 814. https://doi.org/10.3390/ rs14040814

Academic Editor: Roberto Orosei

Received: 22 December 2021

Accepted: 2 February 2022

Published: 9 February 2022

Publisher's Note: MDPI stays neutral with regard to jurisdictional claims in published maps and institutional affiliations.

Copyright: (C) 2022 by the authors. Licensee MDPI, Basel, Switzerland. This article is an open access article distributed under the terms and conditions of the Creative Commons Attribution (CC BY) license (https:// creativecommons.org/licenses/by/ $4.0 /)$.

\begin{abstract}
Lunar floor-fractured craters (FFCs) are a distinguished type of crater found on the surface of the Moon with radial, concentric, and/or polygonal fractures. In the present study, we selected the Posidonius FCC to explore the mineralogy, morphology and tectonic characteristics using remote sensing datasets. The Posidonius crater is vested with a wide moat of lava separating the crater rim inner wall terraces from the fractured central floor. Lunar Reconnaissance Orbiter's (LRO) images and Digital Elevation Model (DEM) data were used to map the tectonics and morphology of the present study. The Moon Mineralogy Mapper $\left(\mathrm{M}^{3}\right)$ data of Chandrayaan-1 were used to investigate the mineralogy of the region through specified techniques such as integrated band depth, band composite and spectral characterization. The detailed mineralogical analysis indicates the noritic-rich materials in one massif among four central peak rings and confirm intrusion (mafic pluton). Spectral analysis from the fresh crater of the Posidonius moat mare unit indicates clinopyroxene pigeonite in nature. Integrated studies of the mineralogy, morphology and tectonics revealed that the study region belongs to the Class-III category of FFCs. The lithospheric loading by adjacent volcanic load (Serenitatis basin) generates a stress state and distribution of the fracture system.
\end{abstract}

Keywords: lunar; Posidonius impact crater; floor fractured crater; lunar morphology; mineralogy; spectral analysis

\section{Introduction}

The impact cratering process and volcanism are two major geological processes of the Moon that shape its surface morphological features. A crater is a circular depression formed due to the hypervelocity impact of a smaller body, i.e., meteoroids [1,2]. Impact cratering processes are not only restricted to the Moon but are also found on the surfaces of other planetary bodies of the solar system [3]. In contrast to impact craters, volcanic processes also lead to circular depressions, but their formation is related to explosions or internal collapse. The Moon is vested with enormous impact craters on the surface ranging from small-sized simple craters to large complex craters/multi-ringed basins. The size of craters range from micrometers to more than $2500 \mathrm{~km}$ [4]. The morphology of an impact crater depends upon several factors, such as the size of the specific crater, rheological properties, and the erosional and degradational processes of the planetary surface [2,5].

The near-earth objects (NEO), namely asteroids and comets, present in the main asteroid belt (between Mars and Jupiter), bombard the Moon and other terrestrial bodies of 
the solar system and develop craters on the surface of the Moon [6]. In this context, lunar floor-fractured craters (FFCs) are a distinguished type of crater found on the surface of the Moon with radial, concentric, and/or polygonal fractures on their floor $[7,8]$. FFCs development mechanisms are related to magmatic near surface intrusion, leading to the formation of a shallow sill or viscous relaxation [7-15]. The recent studies strongly indicate that FFC formation is due to magmatic intrusion and sill formation $[8,16,17]$. Schultz et al. categorized these FFC lunar craters into six classes based on their morphological characteristics using Lunar Orbiter (LO) photographs [7].

Furthermore, Jozwiak et al. (2012) analyzed the Lunar Orbiter Laser Altimeter (LOLA) and Lunar Reconnaissance Orbiter Camera (LROC) to characterize their morphological features and map their distribution around the moon [8]. Among these data, a few FFCs were investigated based on morphology, mineralogy, and chronological characteristics using remote sensing datasets of recent missions, such as Oppenheimer, Atlas, Gassendi, Humboldt, Lavoisier, etc. In the case of Class-III FFCs, the Gassendi and Lavoisier craters were investigated using datasets of recent lunar missions [18-22]. Other Class-III FFCs remain unexplored.

Next, mineralogy furnishes clues for understanding the composition and evolution of the lunar crust. In general, lunar surface mineralogy and lithologies are characterized by/composed of four main minerals: plagioclase, pyroxene, olivine, and ilmenite, and other minor components/accessory minerals. The determination of lithological rock types could be performed based on the relative fractions of the abovementioned minerals. The lunar highland materials/rocks are probably formed during the differentiation of a global lunar magma ocean (LMO), when buoyant plagioclase accumulated to the upper crust to produce anorthositic rich materials due to its lesser density. Unlike highlands, the mare basalts are rich in ferrous and titanium. Furthermore, mare basalts are depleted in aluminum oxide $\mathrm{Al}_{2} \mathrm{O}_{3}[4,5,23,24]$. In this context, the hyperspectral dataset, such as $\mathrm{M}^{3}$, plays a vital role in determining minerals and rock types of the lunar surface due to absorption bands within the visible and near infrared region [25-29]. The absorption zones are related to electronic and vibrational processes within the crystal lattice of minerals [30,31].

The plagioclase is the most abundant mineral present on the Moon and has an absorption around $1250 \mathrm{~nm}$ wavelength [32]. It is a transparent mineral, having high albedo properties. The slight mixture with other minerals is difficult to distinguish based on the investigation of the visible and near infrared region. Due to high-pressure events such as impact cratering of more than $\sim 10$ and $30 \mathrm{GPa}$, the plagioclase absorption is weakened [33-35]. The plagioclase is the main component in the anorthositic highlands of the Moon [32,36]. Furthermore, the most common iron-bearing material on the lunar surface is pyroxene, which shows absorption bands around 1000 and $2000 \mathrm{~nm}$ [37]. The band center position of absorption bands moves to longer wavelengths with increasing contents of $\mathrm{Fe}^{+2}$ and $/ \mathrm{or} \mathrm{Ca}^{+2}$. The second most common iron-bearing mineral is olivine, which shows broad absorption bands around the $1050 \mathrm{~nm}$ wavelength region $[29,38]$.

The class-III FFCs have characteristics such as a wide moat between the crater wall and the interior, radial/polygonal fractures on the crater floor, and a terraced wall opposite the nearby mare region. Some prominent Class-III category FFCs include Gassendi, Taruntius, Lavoisier, Haldane and Runge [8]. The present study takes the Posidonius FFC for detailed interpretation and mapping with recent lunar orbital datasets. The Posidonius crater belongs to the Class-III category of FFCs due to its wide moat of lava separating the crater rim inner wall terraces from the fractured central floor. The fractures are polygonal, radial or concentric in structure. The aims and goals of the present research study include: (1) mapping and investigating the morphological characteristics and tectonic features of the Posidonius FCC using Lunar Reconnaissance Orbiter Camera's (LROC) Wide Angle Camera (WAC) images and LRO Lunar Orbiter Laser Altimeter's (LOLA) Digital Elevation Model (DEM); (2) determining and characterizing the age of the Posidonius crater and its moat mare units using crater size frequency distribution (CSFD) using LRO datasets; (3) performing compositional and mineralogical analysis using Chandrayaan-1 Moon Min- 
eralogy Mapper $\left(\mathrm{M}^{3}\right)$ data; and (4) searching for mineralogical evidence for the magmatic intrusion and (5) stratigraphical evolution of the study region.

\section{Study Area}

Posidonius is a floor-fractured impact crater in the north-eastern part of the Serenitatis basin main rim, with a latitude and longitude of $35^{\circ} 20^{\prime} 0^{\prime \prime} \mathrm{N}, 27^{\circ} 20^{\prime} 0^{\prime \prime} \mathrm{E}$ and $28^{\circ} 0^{\prime} 0^{\prime \prime} \mathrm{N}$, $33^{\circ} 30^{\prime} 0^{\prime \prime} \mathrm{E}$, as shown in Figure 1. Analysis of the Apollo 17 felsic clast of breccia rocks and age dating concluded that the Serenitatis impact event occurred $\sim 3.87 \pm 0.04 \mathrm{Ga}[39,40]$, which is near to the age (time period) of the Imbrium impact event $(3.85 \mathrm{Ga})$. The Serenitatis crater displays mass concentrations (Mascon) inside it and is filled with several series of magmatic activities [41-43]. Multi ring transition from complex craters occurs during impact events of more than $100 \mathrm{~km}$ [2]. The pre-impact morphology and present fracture system of the Posidonius crater is influenced by the Serenitatis impact. A wide moat is observed between the floor and the inner wall, with sinuous rilles in the moat of lava. The Posidonius floor is vested with the fracturing of grabens and a central peak ring. The significant and unique morphology of the study region led it to be chosen for detailed morphological mapping using LRO datasets and mineralogical investigation using highresolution hyperspectral datasets.

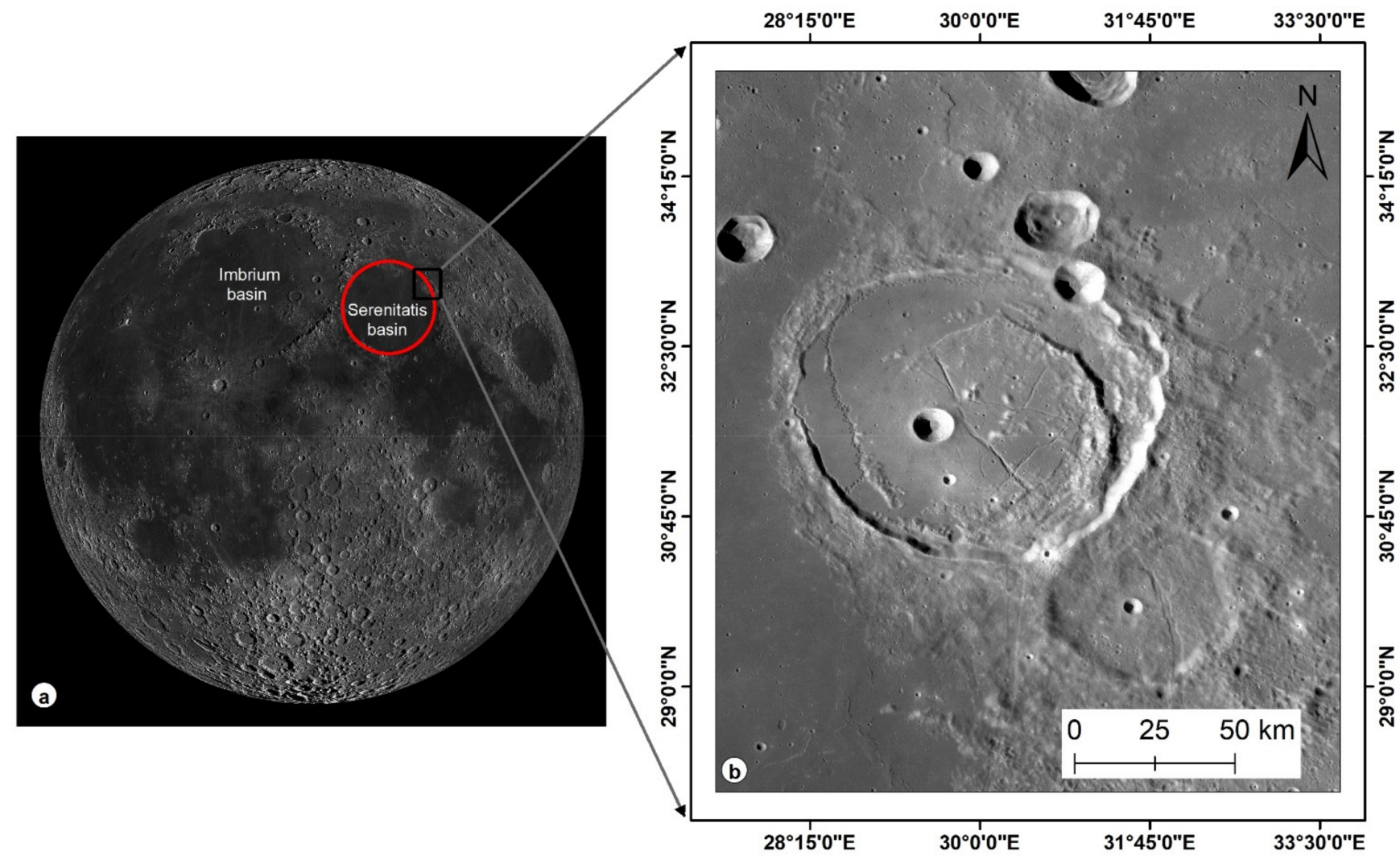

Figure 1. Key map of the study area. (a) Near side of the Moon, Serenitatis basin rim is shown as a red circle and (b) LRO WAC subset for Posidonius floor-fractured lunar impact crater. The Posidonius crater is in the north-western portion of Serenitatis rim.

\section{Data Collection and Processing Methodology}

In the present study, the Lunar Reconnaissance Orbiter's (LRO) Lunar Reconnaissance Orbiter Camera (LROC) Wide Angle Camera (WAC) was used for morphological mapping and interpretation. LROC WAC provides a spatial resolution of $100 \mathrm{~m}$ in 7 color bands. LROC WAC mosaic data were used as a base map for morphological mapping and interpretations [44]. 
LRO's Lunar Orbiter Laser Altimeter (LOLA) Digital Elevation Model (DEM) was utilized for detailed topography analysis in the region. Highly accurate global coverage of DEM points gives accurate DEM values and has become a reference geodetic framework for the topographical analysis among the researchers of lunar communities with a spatial resolution of $118 \mathrm{~m}[45,46]$.

The Chandrayaan- $1 \mathrm{M}^{3}$ is an imaging spectrometer/hyperspectral mapper that provided the first high-resolution spatial and spectral data of most parts of the lunar surface. The primary science goal of $\mathrm{M}^{3}$ is to characterize and map lunar surface mineralogy in the context of lunar geologic evolution over a period of time [47,48]. $\mathrm{M}^{3}$ provides a spectral range from 430 to $3000 \mathrm{~nm}$, covering visible and near infrared data with $10 \mathrm{~nm}$ spectral sampling of 85 contiguous spectral bands. Two modes of spatial resolution are providedone is a global mode with $140 \mathrm{~m} /$ pixel resolution and the other is a target mode with $70 \mathrm{~m} /$ pixel resolution. Five optical periods of OP1A, OP1B, OP2A, OP2B, OP2C covering dates from 18th November 2008 to 16th August 2009 were used. The data available from L0 raw space crate data were improvised with calibrations, photometric correction, geometry correction, etc., as L1b data $[26,47,48]$. The following $\mathrm{M}^{3}$ strips were utilized in the present study: M3G20090731T005012, M3G20090730T205153, and M3G20090730T163918.

The morphological features of the Posidonius floor-fractured crater related to the impact cratering process and volcanism are mapped in GIS environment using LRO WAC image and LOLA DEM. Fortezzo et al. published geological map shape files updated and mapped morphological features inside the Posidonius crater and surrounding region. Many new morphological features, such as central peaks, the crater floor, wall, etc., not present in the Fortezzo et al. map were mapped in the present study [49]. The precise mapping and interpretation by visualization in the GIS environment is coupled with the 3D module. The reconstruction of morphological characteristics of the real-world structures are constructed through scaled digital models. This constitutes an essential step in any geological and engineering environment, offering a good 3D perspective of its characteristics to obtain a better understanding of the particular object of interest [50]. Three-dimensional models provide a more objective, realistic and enhanced environment for geological analysis [51]. Three-dimensional geological modeling has become a powerful tool for understanding geological structures and is implemented in fields of geomorphic mapping and other fields of applied geology [52-56]. The topographic profiles were drawn across the various morphological features using LOLA DEM, which helped us to comprehend the surface variation differences and their connections. These topographical profiles have been extensively used to study the height of craters, sinuous rilles and fracture grabens.

The lunar geological timescale has been divided into five distinct periods, namely pre-Nectarian (>3.92 Ga), Nectarian (3.92-3.84 Ga), Imbrian (Lower: 3.84-3.8; Upper: 3.8-3.2), Eratosthenian $(3.2-1.1 \mathrm{Ga})$ and Copernican ( $<1.1 \mathrm{Ga})$ [57]. The relative and absolute model ages of the homogenous units of the lunar surface were determined using the remote sensing-based crater size-frequency distributions (CSFD) method. This is a wellestablished and adequately applied method for the determination of the chronology of lunar surficial features [58-61]. In the present study, to determine the absolute model age of the homogenous units, the CraterTools module was used for mapping craters [61]. The obtained density, diameters and area of the craters was fed into the Craterstat2 statistical software and fitted with Neukum et al.'s (2001) production function for the determination of absolute model ages of the homogeneous basaltic units [60].

Precise mapping and quantitative evaluation of rock and minerals of planetary surfaces can be explored by optical remote sensing techniques. In particular, the hyperspectral data of $\mathrm{Ch} 1-\mathrm{M}^{3}$ are widely utilized for the precise mapping and discrimination of mineral mixtures. Hyperspectral datasets are processed using ENVI classic image analysis and processing software. A simple band ratio and RGB color composite images were generated to find the lithological diversity and rock types of the Posidonius crater region. In order to ascertain the maturity variation in the crater, the band ratio $(950 / 750)$ was derived. In 
addition, the integrated band depth (IBD), and rock type color composite images were also derived to perceive the mineralogical diversity in the region.

\subsection{Integrated Band Depth (IBD) Analysis-Based Color Composite}

To find the lithological diversity and mafic mineralogy of the Posidonius crater region, a RGB color composite image was produced based on the integrated band depth (IBD) analysis. IBD is a powerful technique in mapping, differentiating and delineating mafic and felsic minerals/rocks of the lunar surface [62]. Pyroxene and volcanic glasses materials with absorptions around 1000 and $2000 \mathrm{~nm}$ can easily be distinguished from the surrounding terrain. The following parameters were used for IBD mapping:

$$
\begin{gathered}
\text { Red channel : IBD@ } 1000 \mathrm{~nm}=\sum_{n=0}^{26}\left(1-\frac{R(789+20 n)}{R C(789+20 n)}\right) \\
\text { Green Channel : IBD@ } 2000 \mathrm{~nm}=\sum_{n=0}^{21}\left(1-\frac{R(1658+40 n)}{R C(1658+40 n)}\right) \\
\text { Blue Channel }:=R 1578 \mathrm{~nm}
\end{gathered}
$$

where $R$ is the reflectance at a particular wavelength and $R C$ is the continuum-removed reflectance. Typically, the reflectance band at $1578.86 \mathrm{~nm}$ is free from absorptions of 1000 and $2000 \mathrm{~nm}$ lunar minerals. Therefore, the RGB color composite was created along with integrated bands of the 1000 and $2000 \mathrm{~nm}$ absorption zone [63-67].

\subsection{Rock Type Color Composite}

In order to differentiate different rock types of the lunar surface, band ratio based RGB color composite images were generated to observe the prominent lunar minerals. The pyroxene, spinel and anorthosite were delineated using the following formula:

$$
\begin{gathered}
\text { Red Channel: }(R 700+R 1200 \mathrm{~nm}) / 2 \times(R 950 \mathrm{~nm}) \\
\text { Green Channel: }(R 1400 \mathrm{~nm} / R 1750 \mathrm{~nm}) \\
\text { Blue Channel: }(R 1000+R 1500) / 2 \times(R 1250)
\end{gathered}
$$

where $R$ is the reflectance at a particular wavelength.

Red, green and blue channel exhibited the pyroxene ratio, spinel ratio and pure anorthosite (PAN) ratio, respectively $[19,68]$.

The reflectance spectra from the fresh materials of the central peak and the fresh craters ( 1-2 km) were collected from Posidonius moat basaltic flow units. After the basaltic unit flows onto the surface of the Moon, it is exposed to the space weathering process, and hence it is unfair to obtain the spectra from weathered/matured basaltic units. Therefore, fresh craters are perfect lithological units for analyzing, interpreting, and characterizing the mare region's basaltic units [69-72]. The critical methodology was followed to select and collect the immature reflectance spectra from fresh craters in order to avoid the unwanted shifting of band center position due to the space weathering process and weak mafic diagnostic absorption features [73-75]. Mostly homogenous single units or averaged 2 by 2 pixel plots depend upon the size of the crater. The reflectance spectra were carefully selected based on the immaturity, fresh and homogenous units without mixtures representing the basaltic units. The optical immaturity trend-based methodology [76,77] was followed for the analysis that was obtained by plotting the fresh craters' spectral units, 950/750 nm vs. $750 \mathrm{~nm}$. The continuum (i.e., the tie points) was initially found by maximizing the band area around the spectral minima between 750 and $1578 \mathrm{~nm}$ and 1578 and $3000 \mathrm{~nm}$; if needed, the fit was manually adjusted. The band parameters were derived from the collected fresh craters' reflectance spectra after the continuum removal process. The three critical band parameters derived from continuum-removed reflectance spectra are the 
band center, band depth, and band area of 1000 and $2000 \mathrm{~nm}$ absorptions [78-81]. The band center is a minimum position of wavelength in third to fourth order of polynomial fit. Iterations were performed after continuum removal of 1000 and $2000 \mathrm{~nm}$ absorptions separately, and polynomial fits were identified. The band depth was one minus the value of the third/fourth order polynomial fit at the band center. The band area was derived by the sum of the area underneath each continuum segment, which was calculated as one minus the value of a particular channel multiplied by its spectra resolution, respectively. Finally, the band area ratio was calculated by dividing the band area of $2000 \mathrm{~nm}$ by the band area of $1000 \mathrm{~nm}$ absorption. Furthermore, these derived parameters were compared with synthetic laboratory-prepared ortho- and clinopyroxenes [28,80].

\section{Results and Discussion}

\subsection{Morphological Mapping and Tectonics of Posidonius Crater \\ 4.1.1. Morphology of Posidonius Crater}

The Posidonius crater is a complex impact structure $112 \mathrm{~km}$ in diameter. The crater has been modified after formation due to the intrusion of a sill, and the floor has been uplifted and fractured. A moat was observed, and the Posidonius crater was classified under Class-III FCC. The elevation profile, generated in the east-west and north-south directions impeccably, depicts the morphological features of the Posidonius crater. The east-west profile (A- $\mathrm{A}^{\prime}$, Figure 2) indicates that the left side is rimless due to destruction related to volcanic activity. A simple crater $11 \mathrm{~km}$ in diameter is present on its floor, with linear and/or radial fractured floors and an elevated rim on the western side. Meanwhile, the north-south profile indicates the elevated rims perfectly, the presence of a moat on the western edge, a dome-shaped central peak/mount, and a terraced inner wall followed by an elevated rim (B-B', Figure 2). The elevation profile drawn across the sinuous rille indicates that it is $\sim 90 \mathrm{~m}$ deep and $2000 \mathrm{~m}$ wide (C-C', Figure 2). The elevation profile drawn across graben indicates that it is $\sim 50 \mathrm{~m}$ deep and $1000 \mathrm{~m}$ wide. The morphological features were mapped in the study region and geological units were named as follows: highland material, terra units, plains, mare units, volcanic channels, crater materials, the central peak ring, the crater floor and the crater wall (Figure 3a). Crater materials are related to impact-related materials, including small and fresh craters (above $3 \mathrm{~km}$ ).

\section{Central Peak Ring and Crater Floor}

The Posidonius central portion is recognized as having a central peak in ring form. The single central peak or more peaks as a ring structure were formed due to their elastic rebounding nature during the modification stage. The central peaks are composed of materials from the deeper portions [1-3,82]. The Posidonius crater has a central peak ring, a fractured floor and wall slumps/terraces. Four distinct mounts of central peaks were observed, and the central peak ring is covered by hummocky floor material. The central peak ring is a common feature present on the surface of the moon for larger complex craters $[83,84]$. The four discontinuous central peak ring massifs are observed with heights ranging from 300 to $500 \mathrm{~m}$. The crater floor is observed to be hummocky and fractured.

\section{Crater Moat and Other Mare Units}

The mare unit appears to be dark in optical remote sensing images and enriched in mafic minerals, i.e., pyroxene [23]. According to the present study region, the mare units are related to two basaltic units-one from Serenitatis and another within the Posidonius crater moat. A long volcanic channel more than $\sim 180 \mathrm{~km}$ in length is present within the moat mare basaltic unit. The volcanic channel is sinuous in nature and splits the mare units in two. 


\section{Crater Wall and Ejecta Blanket}

The crater walls are elongated on three sides other than west. The crater walls are slumped and terraced, which is observed in the eastern part, whereas the western inner wall is covered by mare basalt of the moat.

\section{Highland and Its Related Materials}

Highland materials present in the study region are remnants of preimpact Posidonius impact materials, which are poor in mafic materials and appear bright in optical images. Terra units are unevenly covered with materials and rocks of an older age and typically consist of plagioclase-enriched anorthositic materials. Plains are landforms of the highland region and are mostly smooth in appearance [42].

\subsubsection{Tectonics of Posidonius Crater}

The Posidonius FCC is present on the rim of the Serenitatis impact basin. Grabens are linear landforms with adown dropped block in the center associated with adjacent blocks due to faults. Normal faults are planar surface discontinuities due to extensional stress expressed as fractional sliding found across the lunar surface [4,85-88]. The FCC nature of the Posidonius is related to the formation of sills rather than extrusion/ viscous relaxation. The lithospheric loading by adjacent volcanic load (Serenitatis basin) generates a stress state and the distribution of fracture system favors the rim location [89-91]. The linear and tectonic features were mapped separately to better understand the surficial process, i.e., radial/elongated fractures, grabens, volcanic channel/sinuous rilles and impact-related circular features.
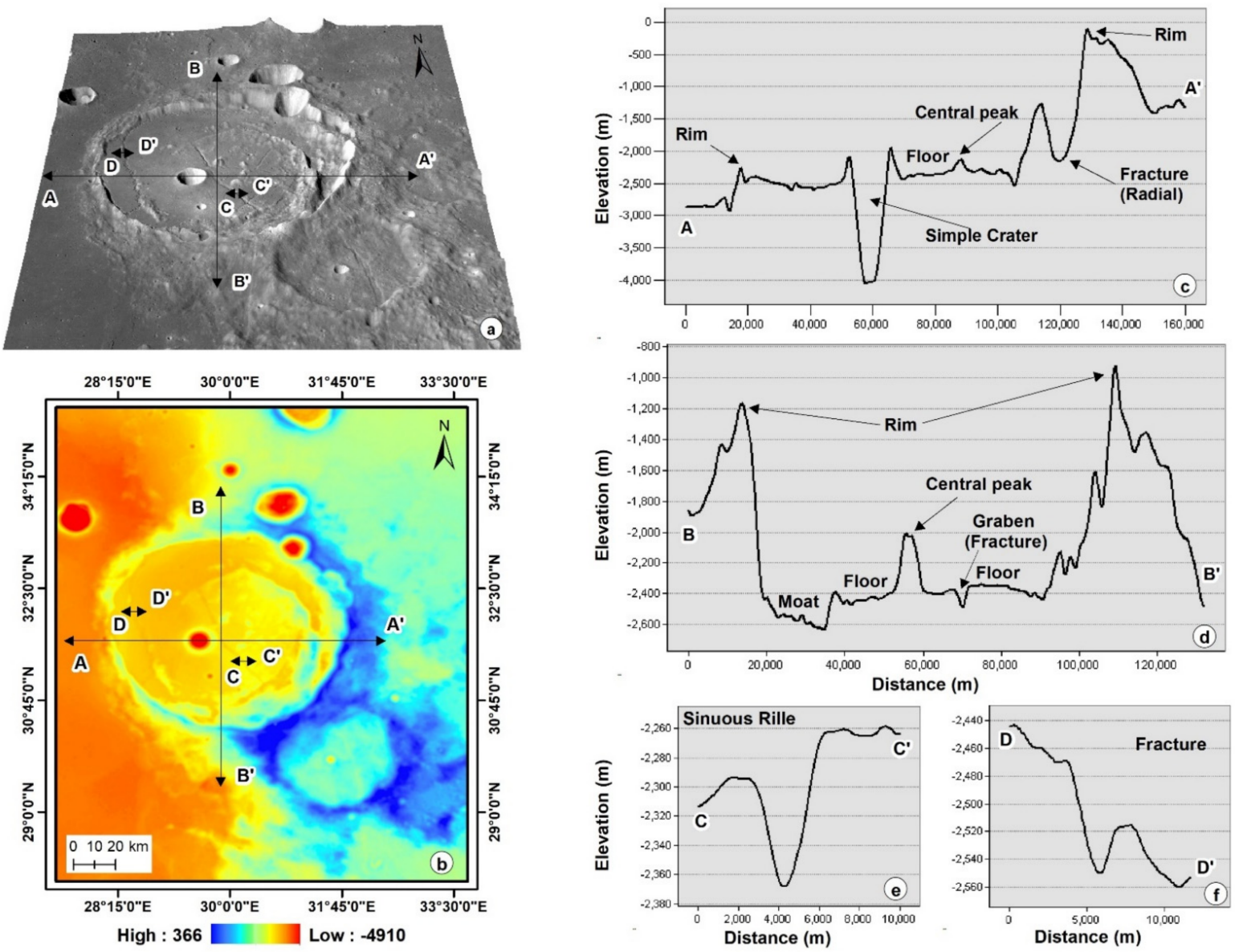

Figure 2. (a) LRO WAC-generated 3D image for detailed topographic analysis; (b) LOLA DEM showing the elevation value of Posidonius crater region; (c-f) topographical profile drawn across the various morphological and tectonic structures. 

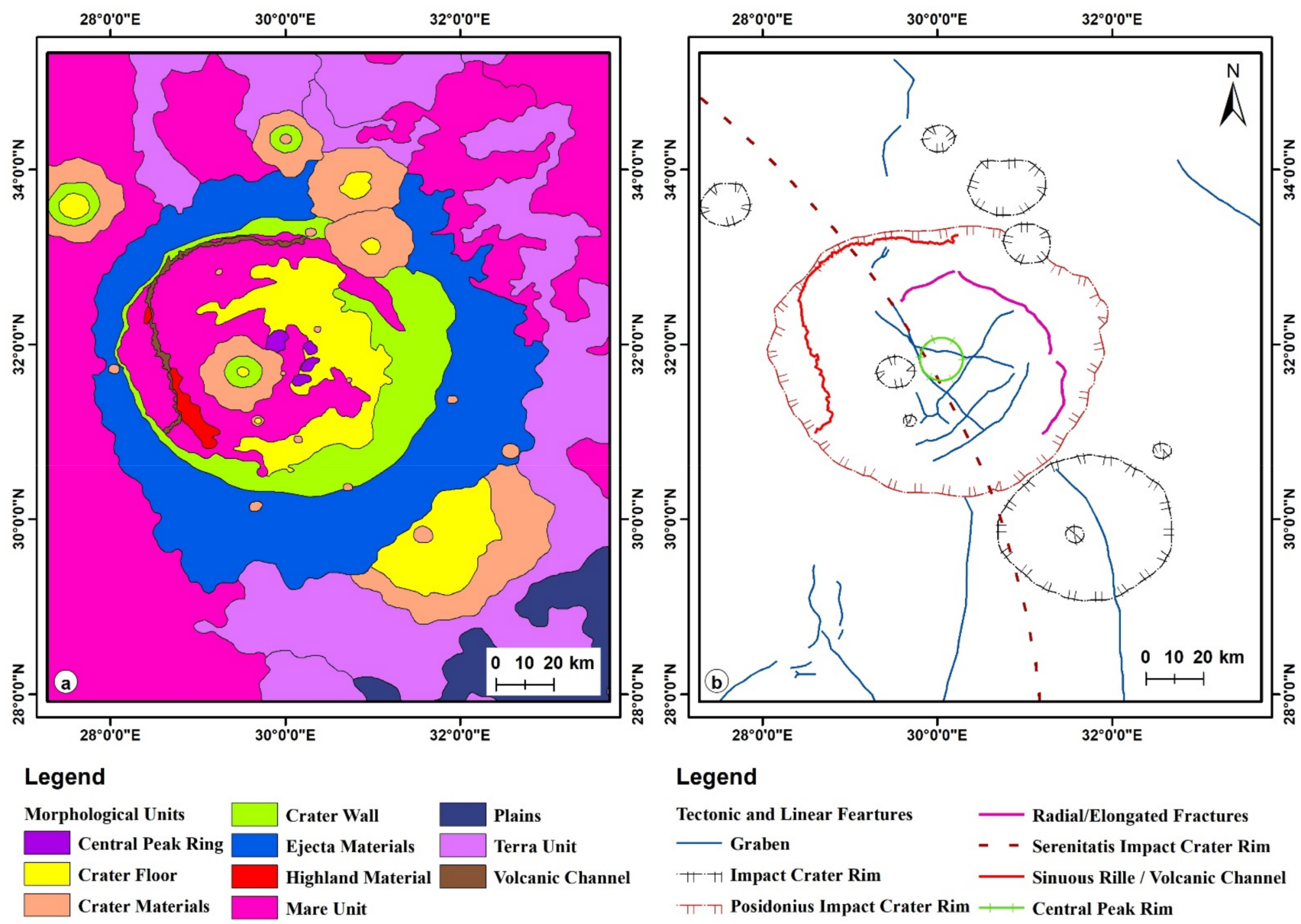

Figure 3. (a) Morphological map of the study area, modified after Fortezzo et al. 2020; (b) tectonic and linear features map of the Posidonius crater region using LRO LROC WAC and DEM data.

\section{Radial/Elongated Fractures}

The radial/elongated fractures were present adjacent to the crater floor or near the floor boundary. Three such radial/elongated fractures were observed within the Posidonius crater region.

\section{Grabens}

Lithospheric loading by adjacent volcanic load (Serenitatis basin) generates a stress fracture, and the true grabens are formed as a result of brittle failure due to the irreversible and rapid propagation of magma and connection of cracks [92]. They are often called fissures, which shows their association with the volcanic process, and they act as the significant features for the generation of fluid migration to reach the surface [93-95]. Five fractures/true grabens were observed within the floor of the Posidonius crater, with length ranges from 43 to $59 \mathrm{~m}$.

Posidonius, Serenitatis and Other Impact Crater Rims

The crater rim is considered a concentric fracture in the tectonic context. These features are also mapped in this study. The Serenitatis rim is drawn by connecting the rim to other than the Posidonius region and the present fracture system also follows it, indicating that the old rim fracture is reactivated by the new ones.

\section{Central Peak Ring and Sinuous Rille/Volcanic Channel}

The transition from the complex craters to peak-ring craters/basins involves the initial destruction and widening of the massive central peak [96]. The down and outward collapse 
of an unstable central massif uplift leads to the formation of a discontinuous central peak ring [97]. These regions have low density and low seismic velocity and extend to a certain depth beneath the surface $[98,99]$. A long sinuous rille of the volcanic channel is perceived in the Posidonius moat. It is named Rima Posidonius, and is $212 \mathrm{~km}$ in length, $0.77 \mathrm{~km}$ in width, and $96.13 \mathrm{~m}$ in depth, with a slope of 0.02 and sinuosity of 1.50 [100]. The sinuous rille formation mechanism is related to lava flow channels with levees of mechanical and/or thermal erosion [101-103].

\subsection{Chronology and Stratigraphy of Posidonius Crater Region}

The Serenitatis impact event was a large impact event that occurred during the period of lunar heavy bombardment (LHB). Analysis of the Apollo 17 felsic clast of breccia rocks and age dating concluded that this impact event occurred at $3.87 \pm 0.04 \mathrm{Ga}$ [39]. The Serenitatis basin displays mass concentrations (Mascon) inside it and is filled with several series of magmatic activities [40-43]. In the present study, the CSFD-based crater age is determined for the Posidonius crater floor and two mare flow units. The Posidonius crater floor shows an age of $3.72 \mathrm{Ga}$. The Posidonius crater moat mare units show ages of 3.5 and $3.34 \mathrm{Ga}$ (Figure 4). According to a new and updated lunar impact crater database by Losiak et al. (2009), the Posidonius crater belong to the upper Imbrian period [104,105], which is consistent with our results regarding the age estimation of the Posidonius crater.
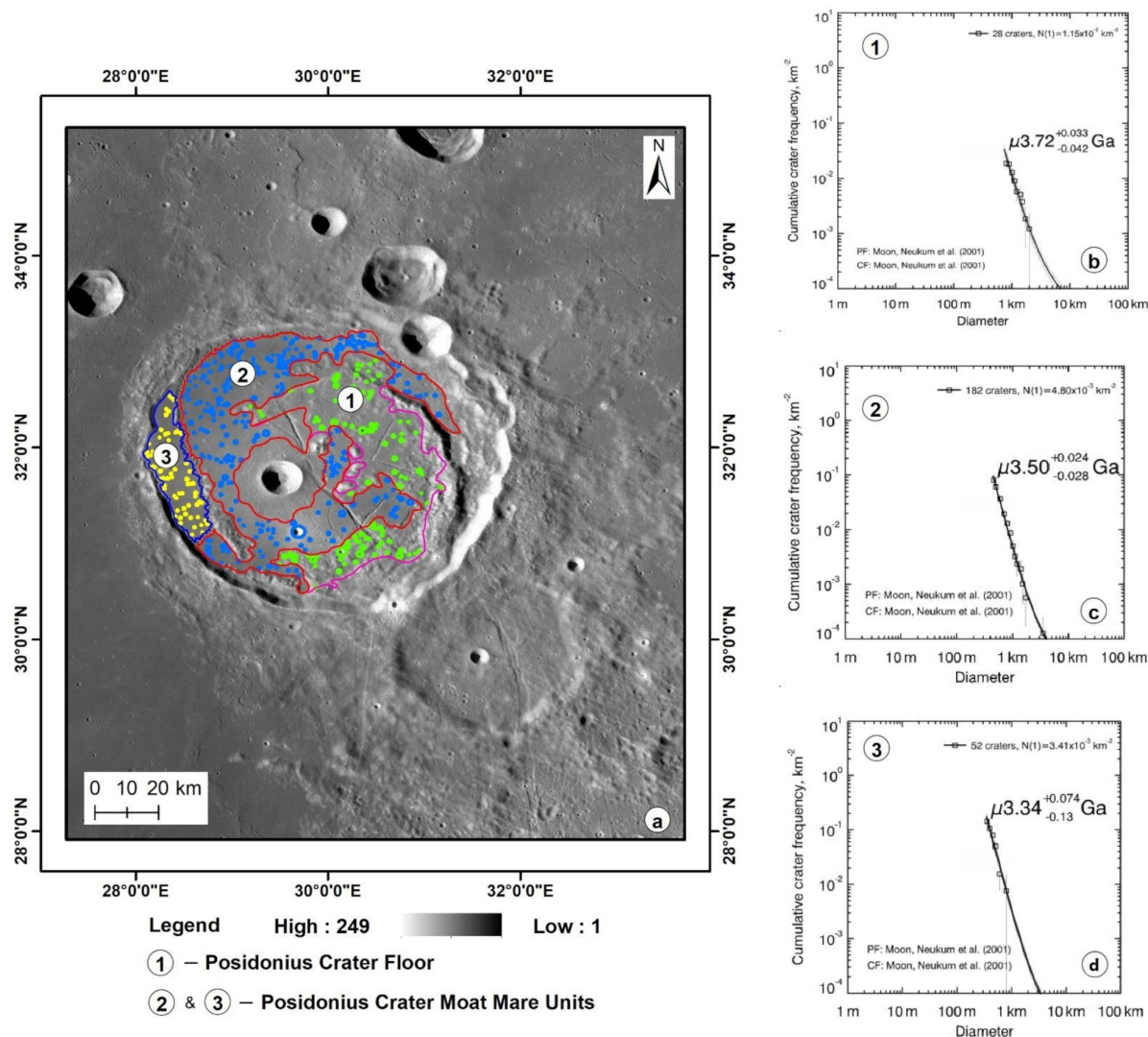

Figure 4. (a) LRO WAC subset for the Posidonius floor-fractured lunar impact crater. The crater size frequency distribution (CSFD)-based ages of (b) Posidonius crater floor and (c,d) Posidonius crater moat mare units.

The formation of larger graben systems on the near side of the moon stopped around $3.6 \pm 0.2 \mathrm{Ga}$. In contrast, the formation of small-scale grabens continued up to $1.2 \mathrm{Ga}[106,107]$. French et al. identified that small scale grabens found in the Posidonius moat mare regions and not superimposed by craters are of a relatively younger age. These Posidonius moats mare small-scale graben crosscut, partially degraded craters ranging in diameter from 80 to 200 in meters. So, these small-scale grabens have a maximum age between the late 
Eratosthenian and early Copernican period of the lunar stratigraphical timescale [11,108,109]. In addition, the grabens not associated with contraction features were used to estimate mare thickness, which was found to be $190 \mathrm{~m}$ for Posidonius moat mare units [109]. The presence of small-scale grabens ranging from 0.5 to $2 \mathrm{~km}$ in width and up to $50 \mathrm{~km}$ in length is linked to the outcomes of intrusive volcanism $[7,107,109]$.

\subsection{Mineralogical Diversity Mapping and Reflectance Spectra Analysis of Posidonius Crater}

The mineralogical diversity of the Posidonius crater region was explored using M3 mosaic data. The reflectance band at $1578 \mathrm{~nm}$ is free from the absorption of mafic minerals, and it could be considered as an albedo image of the region (Figure 5a). A band ratio of $950 / 750 \mathrm{~nm}$ is generated to depict the comparative stratigraphy of geological units and is color coded with red to blue (small to high). The fresh craters appear red in tone and have lower values (1), as shown in Figure 5b. The northern side peak-ring massifs also appear red in tone, indicating the presence of younger materials (2). The mare units related to Serenitatis and the Posidonius moat appear intermediate blue in color (3). The ejecta blanket of Posidonius crater exhibits higher values and indicates older materials (4).
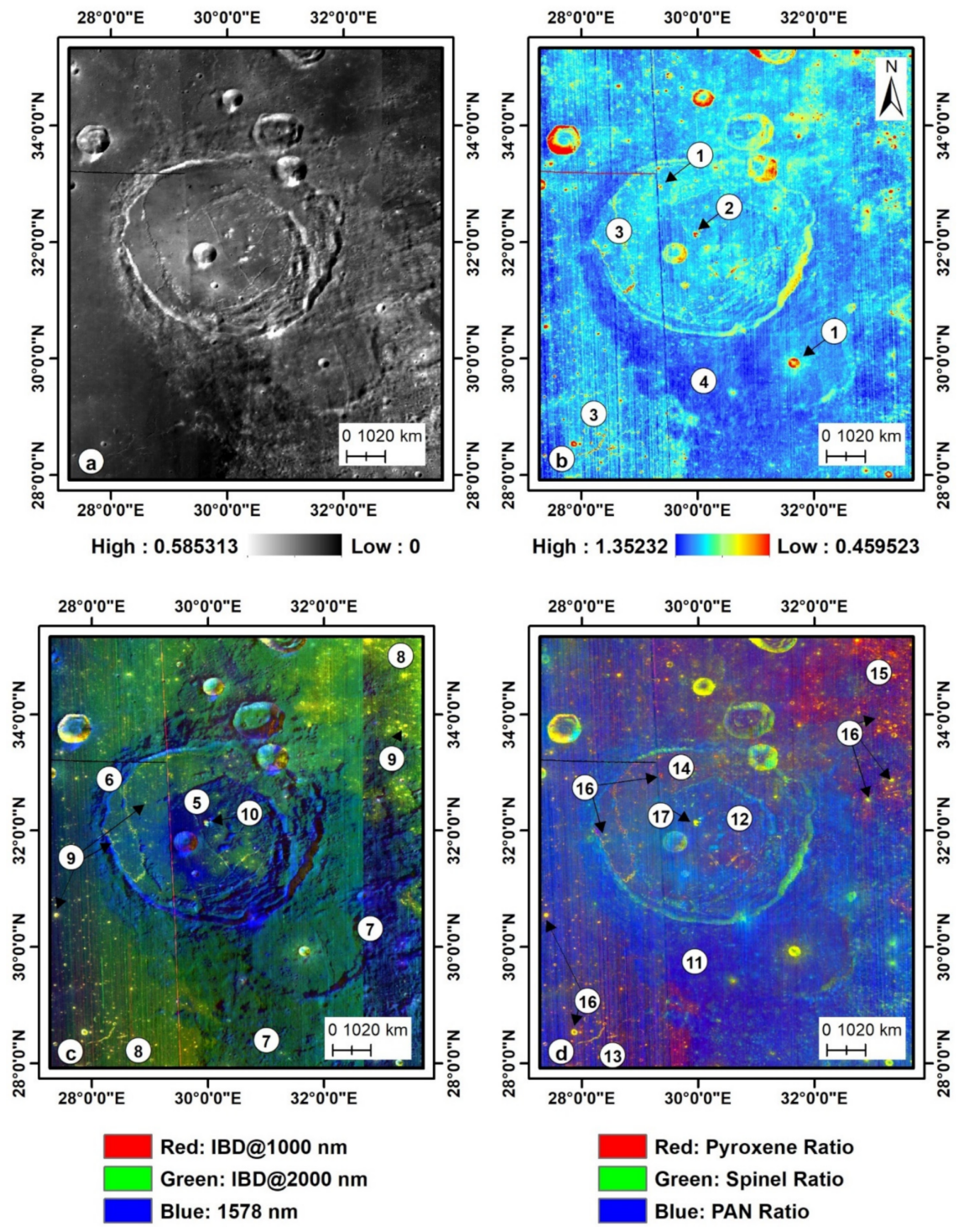

Figure 5. (a) Albedo image of $\mathrm{M}^{3}$ reflectance band at $1578 \mathrm{~nm}$; (b) simple band ratio of 950/750 nm, fresh and young surfaces exhibit lower value; (c) integrated band depth analysis-based color composite image; (d) rock type color composite of the Posidonius crater region. 
In order to map the mineralogical/lithological diversity of the Posidonius crater region, two RGB-based color composite images were generated using IBD analysis and rock type color composite. The IBD-based color composite is shown in Figure 5c. The presence of blue color indicates plagioclase-enriched anorthositic highland materials and a low content of mafic minerals. The Posidonius floor (5), rim (6) and ejecta blanket (7) appear blue in the IBD-based color composite image. The mare units appear green to pale yellow in color (8). The fresh craters appear yellow in color, indicating the presence of pyroxene. Pyroxene will have absorption around 1000 and $2000 \mathrm{~nm}$ [29,36,37]. The fresh craters in the Serenitatis mare units, Posidonius moat mare and north-eastern mare units appear bright yellow in color (9). The one among the massifs of the central peak ring also appears bright yellow to white in color, indicating the presence of low calcium pyroxene and could be categorized as noritic in nature (10), as shown in Figure 4c. This specifies that the intrusion process has taken place in one massif of the Posidonius crater peak ring structures. The central peaks are preferential and favorable sites for intrusions to reach the surface from the sub-surface [16].

The rock type color composite is generated and shown in Figure $4 \mathrm{~d}$. The Posidonius ejecta blanket (11), floor (12) appears blue in color, indicating anorthositic-rich materials. Mare units related to Serenitatis (13), the Posidonius moat (14) and others (15) appear in a red tone, which indicates that they are mafic in nature. The fresh craters in various mare basalts units appear bright yellow, which strongly indicates the presence of pyroxene (16). The one among the five central peak massifs vested in the northern central region also appears bright yellow in color (17, Figure $5 \mathrm{~d})$. The absence of green color indicates this floor-fractured crater is lacking spinel-bearing minerals.

Furthermore, the color composite image is validated by collecting spectra from various lithological units of the Posidonius FFC region (Figure 6). The rock type color composite is taken into account for the validation of reflectance spectra and compared with RELAB data for the better interpretation and naming of minerals [110]. The matured Posidonius moat mare unit reflectance spectra show minor absorption at 990 and $2100 \mathrm{~nm}$ and indicate mafic bearing minerologies (1). The bright yellow fresh crater from the mare basalts of the north-eastern part of the Posidonius FFC shows strong 990 and $2150 \mathrm{~nm}$ absorption and indicates clinopyroxene augite (2). One among the central peak massifs shows a bright yellow color tone and exhibits strong absorption around 990 and $1900 \mathrm{~nm}$, which indicates that it is noritic in composition (3). The presence of low calcium-bearing noritic lithological units agrees with and confirms the intrusion process. The yellow appearance of one of the fresh craters in the Posidonius moat mare collected reflectance spectra shows strong absorption at 1000 and $2100 \mathrm{~nm}$ and indicates high calcium pyroxene levels (4). The Posiodnius FCC ejecta blanket appears in shades of blue in the rock type color composite image and indicates plagioclase-rich anorthositic highland materials. The two reflectance spectra were collected from these units: one is from a bright fresh crater and other from a matured crater with a pale blue tone (5 and 6, Figure 6). Both craters show no mafic absorption and featureless spectra. The fresh crater collected reflectance spectra have a bright tone, demonstrating that Posidonius ejecta possess an overall high reflectance value. These featureless spectra are related to the presence of plagioclase $[35,36]$.

In addition, the reflectance spectra were collected, and band parameters were derived for finding the pyroxene chemistry of the Posidonius FCC mafic units. The reflectance spectra were collected from the noritic massif of the central peak ring and fresh craters of the Posidonius moat mare unit by utilizing $\mathrm{M}^{3}$ data of Chandrayaan- 1 . The absorption band depths at 1000 and $2000 \mathrm{~nm}$ were investigated by deriving the band parameters such as band center, band depth and band area (Table 1). The locations of reflectance spectra collected from the Posidonius FCC region are shown in Figure 7. The noritic massif of the central peak ring shows strong absorption in 926.33 and $1925.67 \mathrm{~nm}$. The fresh crater's reflectance spectra from the Posidonius moat mare units demonstrate that the $1000 \mathrm{~nm}$ absorption band center range from 949.65 to $1049.85 \mathrm{~nm}$, and the $2000 \mathrm{~nm}$ absorption band center ranges from 2074.67 to $2201.25 \mathrm{~nm}$. The band parameters such 
as the band center, band depth and band area are derived using 1000 and $2000 \mathrm{~nm}$ mafic absorption from the analysis of hyperspectral data based on Gaffey et al. 2002 [111]. The derived band center and shape parameters allow us to estimate endmember mineralogy and their composition [84,112]. The noritic massif of the central peak exhibits absorption of around 930 and $1900 \mathrm{~nm}$ and confirms the plutonic intrusion of low-calcium pyroxene. The reflectance spectra from the fresh craters of the Posidonius crater moat mare unit exhibit absorption around 950 to $1000 \mathrm{~nm}$ and 2000 to $2200 \mathrm{~nm}$. These are calcium-rich mineralogical units, and they contain clinopyroxene pigeonite.
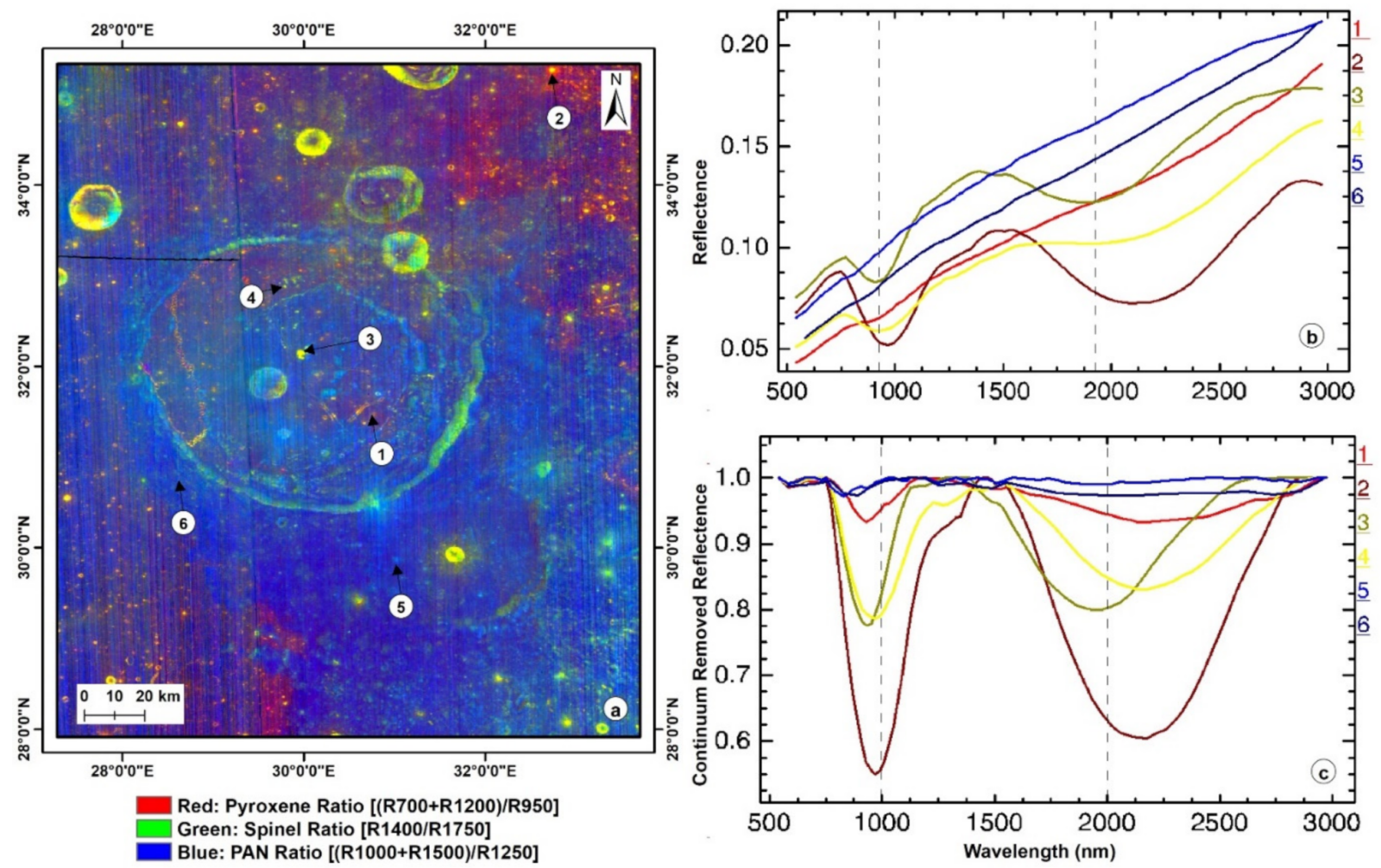

Figure 6. (a) Rock type color composite of the Posidonius crater region; (b) reflectance spectra collected from various lithological units; (c) respective continuum-removed reflectance spectra (dashed lines at 1000 and $2000 \mathrm{~nm}$ ).

Table 1. Posidonius crater fresh craters/materials reflectance spectra-derived band parameters.

\begin{tabular}{|c|c|c|c|c|c|c|c|c|}
\hline \multirow[b]{2}{*}{ S. No. } & \multirow{2}{*}{$\begin{array}{l}\text { Name } \\
\text { (Code) }\end{array}$} & \multicolumn{7}{|c|}{ Band Parameters } \\
\hline & & Band Center & $\begin{array}{l}1000 \mathrm{~nm} \\
\text { Band Depth }\end{array}$ & Band Area & Band Center & $\begin{array}{l}2000 \mathrm{~nm} \\
\text { Band Depth }\end{array}$ & Band Area & $\begin{array}{c}\text { Band Area } \\
\text { Ratio }\end{array}$ \\
\hline 1 & PRS1 & 926.33 & 0.21 & 40.56 & 1925.67 & 0.16 & 98.50 & 2.42 \\
\hline 2 & PRS2 & 949.65 & 0.17 & 44.41 & 2074.67 & 0.16 & 130.77 & 2.94 \\
\hline 3 & PRS3 & 966.29 & 0.17 & 48.95 & 2167.73 & 0.16 & 128.90 & 2.63 \\
\hline 4 & PRS4 & 972.61 & 0.18 & 48.97 & 2167.46 & 0.17 & 130.71 & 2.67 \\
\hline 5 & PRS5 & 1049.85 & 0.20 & 99.48 & 2173.07 & 0.15 & 118.79 & 1.19 \\
\hline 6 & PRS6 & 969.29 & 0.14 & 38.2 & 2170.36 & 0.15 & 119.83 & 3.13 \\
\hline 7 & PRS7 & 983.65 & 0.18 & 61.10 & 2156.68 & 0.19 & 145.36 & 2.38 \\
\hline 8 & PRS8 & 976.85 & 0.15 & 39.15 & 2188.29 & 0.13 & 103.53 & 2.64 \\
\hline 9 & PRS9 & 973.19 & 0.16 & 44.17 & 2201.25 & 0.14 & 105.85 & 2.39 \\
\hline 10 & PRS10 & 964.26 & 0.15 & 39.35 & 2188.65 & 0.13 & 94.57 & 2.40 \\
\hline 11 & PRS11 & 973.70 & 0.18 & 52.55 & 2192.59 & 0.15 & 115.38 & 2.19 \\
\hline 12 & PRS12 & 990.26 & 0.20 & 66.17 & 2167.46 & 0.17 & 130.71 & 1.97 \\
\hline
\end{tabular}



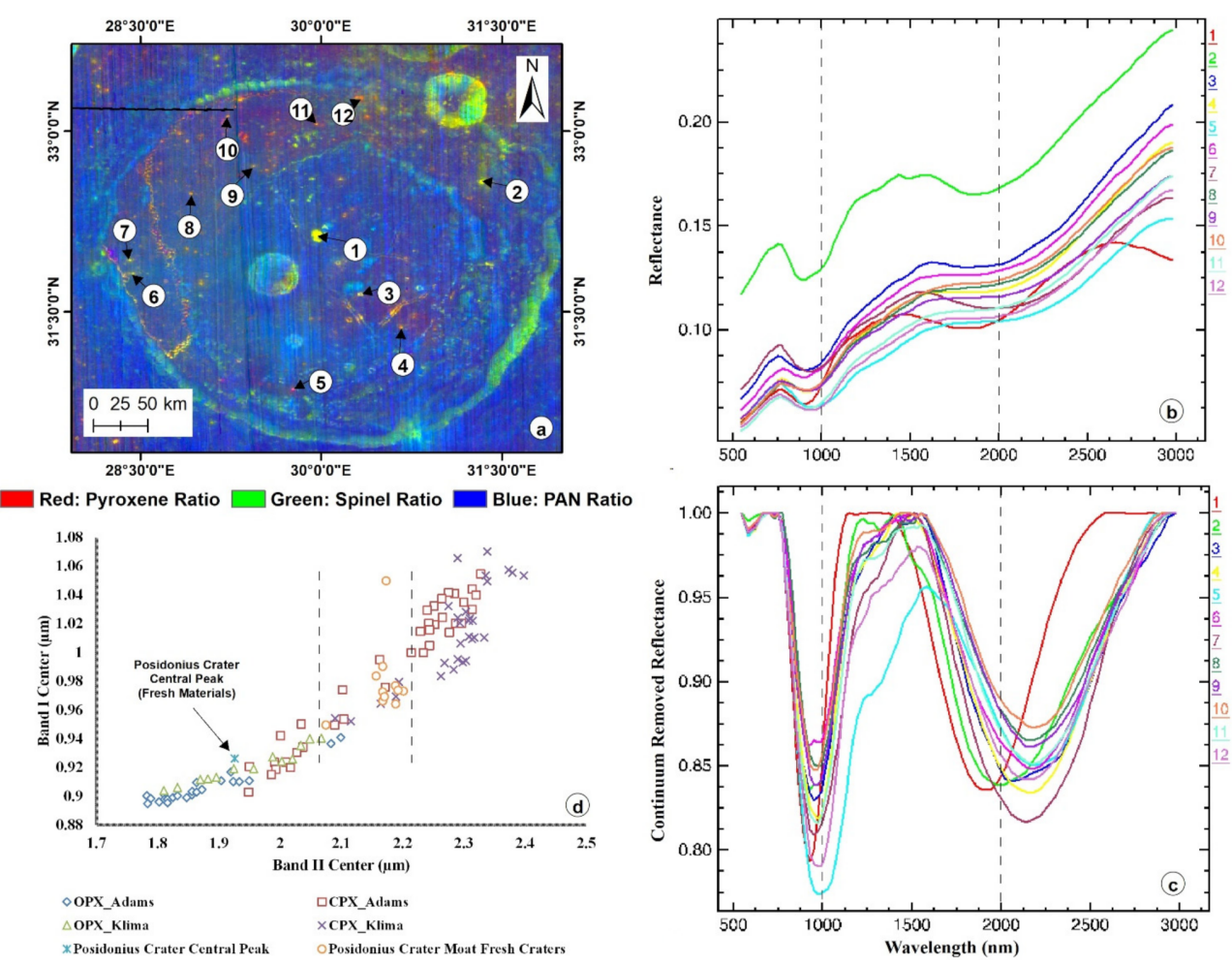

Figure 7. (a) Rock type color composite image of Posidonius crater region showing the reflectance spectra collected locations; (b) reflectance spectra of fresh craters of Posidonius crater region along with central peak fresh materials; (c) respective continuum removed reflectance spectra; (d) Band II center vs. Band I center of Posidonius crater fresh craters/materials with synthetic orthoand clinopyroxene.

In the present study, this type of FCC shows dike intrusion underneath and close to the surface but fails to erupt, due to the host impact crater and crustal structure. The dike intrusion is a potential cause for the grabens in the crater floor and low-density breccia zones $[17,113]$. The breccia lenses beneath them extend to a few tens of kilometers. The central peak or rings of peaks are favorable for mafic pluton intrusion/alteration globally on the lunar surface [114,115]. The intrusive mafic plutonic geological activity plays a vital role in shaping the Poisonous FCC's present morphology and mineralogy.

The morphological and mineralogical characteristics of the Posidonius crater were compared with those of other similar class-III FCCs. The Gassendi crater is $110 \mathrm{~km}$ wide and vested in the western near side of the Moon around the north of Mare Humorum. The central peak exhibits anorthositic-rich units, and olivine is found in one site. The Gassendi floor and fractures are gabbroic in composition, enriched in high-calcium pyroxene along with ferrous and titanium enrichment. Igneous intrusion shaped the present state of the Gassendi crater after the impact cratering process. The mare units within the Gassendi crater are rich in calcium pyroxene, and band parameters analysis indicates that they vary from a sub-calcic to calcic composition. The CSFD-based age estimation of mare units shows that they were formed 3.59 to $2.99 \mathrm{Ga}$ ago $[20,21]$. The Posidonius FCC also possesses similar and consistent results in size, morphology, fracture system and igneous intrusion. In the case of the Lavoisier FCC, it is $70 \mathrm{~km}$ in diameter and vested at the western edge of the Oceanus Procellarum. The pyroclastic deposits are found on the floor adjacent to grabens [22]. It differs from the Posidonius FCC's morphology and minerology.

\section{Conclusions}

In the present study, the LROC WAC image and DEM data have been utilized for mapping the morphological and tectonic features in the Posidonius FCC. The CSFD-based ages were estimated for homogenous units. The Chandrayaan- $1 \mathrm{M}^{3}$ data have been extensively 
used for the generation of color composite images, the band ratio and the characterization of reflectance spectra in the visible and near infrared region effectively to delineate the various lithology/mineralogical units. The study highlights the following outcomes:

$\checkmark \quad$ The RGB color composite images derived using integrated band depth (IBD) and rock type analyses support the delineation of mineralogical units and lithological diversity of the studied region. In this regard, it is observed that one of the four central peak ring massifs contains noritic-rich low-calcium pyroxene (mafic pluton). The analysis of reflectance spectra band parameters of fresh craters in the mare units indicates the composition of the clinopyroxene (pigeonite). Moreover, the collected reflectance spectra and their band parameters of fresh crater units and mare units were validated and compared with existing RELAB data.

$\checkmark \quad$ Morphological characteristics highlight the various surface components, such as highland material, terra units, plains, mare units, volcanic channels, crater materials, the central peak ring, the crater floor and the crater wall.

$\checkmark \quad$ Mapping of linear and tectonic characterization has been obtained to ascertain the surficial process of the crater with different units, such as grabens, radial/elongated fractures, volcanic channels/sinuous rilles and impact-related circular features, and the respective unit ranges were observed.

$\checkmark \quad$ The crater size frequency distribution (CSFD)-based age dating shows the Posidonius crater is $3.72 \mathrm{Ga}$ old and belongs to upper Imbrian period. The moat mare units show ages of 3.5 and $3.34 \mathrm{Ga}$.

$\checkmark$ From the overall observations, it is observed that the Posidonius floor-fractured complex crater (diameter of $112 \mathrm{~km}$ ) comes under the type-III FFC, which is vested with a central peak ring and moat. Moreover, the mineralogically evident intrusion of a sill and dike favors the conditions for the fracture system. Eventually, it is shown that the origin and evolution of the crater occurred due to stress and strain, which were generated due to adjacent intrusive mafic plutonic lithospheric loading from the Serenitatis basin's formation.

Author Contributions: Conceptualization, M.S., I.B.S. and P.R.K.; methodology, M.S., I.B.S. and P.R.K.; software, M.S. and P.R.K.; validation, M.S., I.B.S. and F.M.H.; formal analysis, P.R.K. and A.K.; investigation, M.S., P.R.K. and A.K.; resources, I.B.S., F.M.H. and Y.N.; data curation, A.K. and C.M.X.; writing-original draft preparation, M.S., I.B.S. and P.R.K.; writing-review and editing, M.S., I.B.S., P.R.K. and A.K.; visualization, F.M.H., Y.N., M.S. and C.M.X.; supervision, I.B.S., funding acquisition, I.B.S. All authors have read and agreed to the published version of the manuscript.

Funding: This project was funded by the Research Office, Zayed University, United Arab Emirates (Project No. R 21005).

Data Availability Statement: Chandrayaan-1 Moon Mineralogical Mapper $\left(\mathrm{M}^{3}\right)$ were downloaded from PDS Geosciences Node Orbital Data Explorer (ODE) (https: / / ode.rsl.wustl.edu/) (Accessed on 17 August 2021). LROC data were downloaded from USGS Astrogeology website.

Acknowledgments: We thank $\mathrm{M}^{3}$ Team, Chandrayaan-1 mission, Indian Space Research Organization (ISRO) and NASA's planetary missions for making the availability of data set in the public domain through web portals.

Conflicts of Interest: The authors declare that they have no known competing financial interests or personal relationships that could have appeared to influence the work reported in this paper.

\section{References}

1. Beals, C.S.; Halliday, I. Impact craters of the Earth and Moon. J. R. Astron Soc. Can. 1965, 59, 199.

2. Melosh, H.J.; Ivanov, B.A. Impact crater collapse. Annu. Rev. Earth Plan. Sci. 1999, 27, 385-415. [CrossRef]

3. Robbins, S.J.; Watters, W.A.; Chappelow, J.E.; Bray, V.J.; Daubar, I.J.; Craddock, R.A.; Beyer, R.A.; Landis, M.; Ostrach, L.R.; Tornabene, L.; et al. Measuring impact crater depth throughout the solar system. Meteorit. Planet. Sci. 2018, 53, 583-637. [CrossRef]

4. Hiesinger, H.; Head, J.W., III. New views of lunar geoscience: An introduction and overview. Rev. Miner. Geochem. 2006, 60, 1-81. [CrossRef] 
5. Hiesinger, H.; Jaumann, R. Chapter 23-The Moon. In Encyclopedia of the Solar System, 3rd ed.; Elsevier BV: Amsterdam, The Netherlands, 2014; pp. 493-538. [CrossRef]

6. Harris, A.W.; Drube, L.; McFadden, L.A.; Binzel, R.P. Near-Earth Objects. In Encyclopedia of the Solar System, 3rd ed.; Elsevier BV: Amsterdam, The Netherlands, 2014; pp. 603-623. [CrossRef]

7. Schultz, P.H. Floor-fractured lunar craters. Earth Moon Planets 1976, 15, 241-273. [CrossRef]

8. Jozwiak, L.M.; Head, J.W.; Zuber, M.T.; Smith, D.E.; Neumann, G.A. Lunar floor-fractured craters: Classification, distribution, origin and implications for magmatism and shallow crustal structure. J. Geophys. Res. Planets 2012, 117, 1-23. [CrossRef]

9. Masursky, H. A preliminary report on the role of isostatic rebound in the geologic development of the lunar crater Ptolemaeus. Astrogeol. Stud. Annu. Prog. Rep. 1964, 1, 102-134.

10. Daneš, Z.F. Rebound processes in large craters. Astrogeol. Stud. Annu. Prog. Rep. 1965, 81-100.

11. Brennan, W.J. Modification of premare impact craters by volcanism and tectonism. Earth Moon Planets 1975, 12, 449-461. [CrossRef]

12. Cathles, L.M. Viscosity of the Earth's Mantle; Princeton University Press: Princeton, NJ, USA, 2015.

13. Hall, J.L.; Solomon, S.C.; Head, J.W. Lunar floor-fractured craters: Evidence for viscous relaxation of crater topography. J. Geophys. Res. Solid Earth 1981, 86, 9537-9552. [CrossRef]

14. Wichman, R.W.; Schultz, P.H. Floor-fractured craters in Mare Smythii and west of Oceanus Procellarum: Implications of crater modification by viscous relaxation and igneous intrusion models. J. Geophys. Res. Planets 1995, 100, 21201-21218. [CrossRef]

15. Dombard, A.J.; Gillis, J. Testing the viability of topographic relaxation as a mechanism of the formation of lunar floor-fractured craters. J. Geophys. Res. 2001, 106, 901-927. [CrossRef]

16. Thorey, C.; Michaut, C. A model for the dynamics of crater-centered intrusion: Application to lunar floor-fractured craters. $J$. Geophys. Res. Planets 2014, 119, 286-312. [CrossRef]

17. Wilson, L.; Head, J.W. Controls on lunar basaltic volcanic eruption structure and morphology: Gas release patterns in sequential eruption phases. Geophys. Res. Lett. 2018, 45, 5852-5859. [CrossRef]

18. Bennett, K.A.; Horgan, B.H.; Gaddis, L.R.; Greenhagen, B.T.; Allen, C.C.; Hayne, P.O.; Bell, J.F., III; Paige, D.A. Complex explosive volcanic activity on the Moon within Oppenheimer crater. Icarus 2016, 273, 296-314. [CrossRef]

19. Pathak, S.; Dagar, A.K.; Bhattacharya, S.; Moitra, H.; Chauhan, M.; Gupta, S. Geological insights into lunar floor-fractured crater Atlas. Icarus 2021, 360, 114374. [CrossRef]

20. Purohit, A.N.; Patel, S.M.; Thaker, A.D.; Solanki, P.M. Compositional and morphological analysis of Gassendi crater. J. Earth Syst. Sci. 2021, 130, 1-23. [CrossRef]

21. Giguere, T.A.; Hawke, B.R.; Gillis-Davis, J.J.; Lemelin, M.; Boyce, J.M.; Trang, D.; Lawrence, S.J.; Stopar, J.D.; Campbell, B.A.; Gaddis, L.R.; et al. Volcanic Processes in the Gassendi Region of the Moon. J. Geophys. Res. Planets 2020, 125, e2019JE006034. [CrossRef]

22. Souchon, A.L.; Besse, S.; Pinet, P.C.; Chevrel, S.D.; Daydou, Y.H.; Josset, J.L.; D’Uston, L.; Haruyama, J. Local spectrophotometric properties of pyroclastic deposits at the Lavoisier lunar crater. Icarus 2013, 225, 1-4. [CrossRef]

23. Papike, J.J. Comparative planetary mineralogy; chemistry of melt-derived pyroxene, feldspar, and olivine. Rev. Mineral. Geochem. 1998, 36, 7-01-7-12.

24. Shearer, C.K.; Hess, P.C.; Wieczorek, M.A.; Pritchard, M.E.; Parmentier, E.M.; Borg, L.E.; Longhi, J.; Elkins-Tanton, L.T.; Neal, C.R.; Antonenko, I.; et al. Thermal and magmatic evolution of the Moon. Rev. Mineral. Geochem. 2006, 60, 365-518. [CrossRef]

25. Pieters, C.M.; Boardman, J.; Buratti, B.; Chatterjee, A.; Clark, R.; Glavich, T.; Green, R.; Head, J., III; Isaacson, P.; Malaret, E.; et al. The Moon mineralogy mapper $\left(\mathrm{M}^{3}\right)$ on chandrayaan-1. Curr. Sci. 2009, 96, 500-505.

26. Green, R.O.; Pieters, C.; Mouroulis, P.; Eastwood, M.; Boardman, J.; Glavich, T.; Isaacson, P.; Annadurai, M.; Besse, S.; Barr, D.; et al. The Moon Mineralogy Mapper (M3) imaging spectrometer for lunar science: Instrument description, calibration, on-orbit measurements, science data calibration and on-orbit validation. J. Geophys. Res. Planets 2011, 116, 1-31. [CrossRef]

27. Staid, M.I.; Pieters, C.M.; Besse, S.; Boardman, J.; Dhingra, D.; Green, R.; Head, J.W.; Isaacson, P.; Klima, R.; Kramer, G.; et al The mineralogy of late stage lunar volcanism as observed by the Moon Mineralogy Mapper on Chandrayaan-1. J. Geophys. Res. Planets 2011, 116, 1-15. [CrossRef]

28. Klima, R.L.; Dyar, M.D.; Pieters, C.M. Near-infrared spectra of clinopyroxenes: Effects of calcium content and crystal structure. Meteorit. Planet. Sci. 2011, 46, 379-395. [CrossRef]

29. Isaacson, P.J.; Pieters, C.M.; Besse, S.; Clark, R.N.; Head, J.W.; Klima, R.L.; Mustard, J.F.; Petro, N.E.; Staid, M.I.; Sunshine, J.M.; et al. Remote compositional analysis of lunar olivine-rich lithologies with Moon Mineralogy Mapper (M3) spectra. J. Geophys. Res. Planets 2011, 116. [CrossRef]

30. Sunshine, J.M.; Pieters, C.M.; Pratt, S.F. Deconvolution of mineral absorption bands: An improved approach. J. Geophys. Res. Solid Earth 1990, 95, 6955-6966. [CrossRef]

31. Clark, R.N.; Rencz, A.N. Spectroscopy of rocks and minerals, and principles of spectroscopy. Man. Remote Sens. $1999,3,3-58$.

32. Cheek, L.C.; Pieters, C.M. Reflectance spectroscopy of plagioclase-dominated mineral mixtures: Implications for characterizing lunar anorthosites remotely. Am. Mineral. 2014, 99, 1871-1892. [CrossRef]

33. Von Engelhardt, W.; Stöffler, D. Stages of shock metamorphism in crystalline rocks of the Ries Basin, Germany. In Shock Metamorphism of Natural Materials; French, N.M., Short, N.M., Eds.; Mono Book Corporation: Baltimore, MD, USA, 1968; pp. 159-168. 
34. Stöffler, D. Progressive metamorphism and classification of shocked and brecciated crystalline rocks at impact craters. J. Geophys. Res. 1971, 76, 5541-5551. [CrossRef]

35. Bruckenthal, E.A.; Pieters, C.M. Spectral effects of natural shock on plagioclase feldspar. In Proceedings of the 15th Lunar and Planetary Science Conference, Houston, TX, USA, 12-16 March 1984; pp. 96-97.

36. Adams, J.B.; Horz, F.; Gibbons, R.V. Effects of shock-loading on the reflectance spectra of plagioclase, pyroxene, and glass. In Proceedings of the 10th Lunar and Planetary Science Conference, Houston, TX, USA, 19-23 March 1979; pp. 1-3.

37. Adams, J.B. Visible and near-infrared diffuse reflectance spectra of pyroxenes as applied to remote sensing of solid objects in the solar system. J. Geophys. Res. 1974, 79, 4829-4836. [CrossRef]

38. Burns, R.G.; Burns, R.G. Mineralogical Applications of Crystal Field Theory; Cambridge University Press: Cambridge, UK, 1993.

39. Staudacher, T.; Dominik, B.; Jessberger, E.K.; Kirsten, T. Consortium Breccia 73255: 40AR-39AR Dating. In Proceedings of the 9th Lunar and Planetary Science Conference, Houston, TX, USA, 13-17 March 1978; pp. 1098-1100.

40. Solomon, S.C.; Head, J.W. Lunar mascon basins: Lava filling, tectonics, and evolution of the lithosphere. Rev. Geophys. 1980, 18, 107-141. [CrossRef]

41. Phillips, R.J.; Conel, J.E.; Abbott, E.A.; Sjogren, W.L.; Morton, J.B. Mascons: Progress toward a unique solution for mass distribution. J. Geophys. Res. 1972, 77, 7106-7114. [CrossRef]

42. Howard, K.A.; Wilhelms, D.E.; Scott, D.H. Lunar basin formation and highland stratigraphy. Rev. Geophys. 1974, 12, 309-327. [CrossRef]

43. Kaur, P.; Bhattacharya, S.; Chauhan, P.; Kumar, A.K. Mineralogy of Mare Serenitatis on the near side of the Moon based on Chandrayaan-1 Moon Mineralogy Mapper (M3) observations. Icarus 2013, 222, 137-148. [CrossRef]

44. Robinson, M.S.; Brylow, S.M.; Tschimmel, M.; Humm, D.; Lawrence, S.J.; Thomas, P.C.; Denevi, B.W.; Bowman-Cisneros, E.; Zerr, J.; Ravine, M.A.; et al. Lunar reconnaissance orbiter camera (LROC) instrument overview. Space Sci. Rev. 2010, 150, 81-124. [CrossRef]

45. Smith, D.E.; Zuber, M.T.; Neumann, G.A.; Lemoine, F.G.; Mazarico, E.; Torrence, M.H.; McGarry, J.F.; Rowlands, D.D.; Head, J.W.; Duxbury, T.H.; et al. Initial observations from the lunar orbiter laser altimeter (LOLA). Geophys. Res. Lett. 2010, 37, 18. [CrossRef]

46. Barker, M.K.; Mazarico, E.; Neumann, G.A.; Zuber, M.T.; Haruyama, J.; Smith, D.E. A new lunar digital elevation model from the Lunar Orbiter Laser Altimeter and SELENE Terrain Camera. Icarus 2016, 273, 346-355. [CrossRef]

47. Besse, S.; Sunshine, J.; Staid, M.; Boardman, J.; Pieters, C.; Guasqui, P.; Malaret, E.; McLaughlin, S.; Yokota, Y.; Li, J.Y. A visible and near-infrared photometric correction for Moon Mineralogy Mapper (M3). Icarus 2013, 222, 229-242. [CrossRef]

48. Besse, S.; Yokota, Y.; Boardman, J.; Green, R.; Haruyama, J.; Isaacson, P.; Mall, U.; Matsunaga, T.; Ohtake, M.; Pieters, C.; et al. One Moon, many measurements 2: Photometric corrections. Icarus 2013, 226, 127-139. [CrossRef]

49. Fortezzo, C.M.; Spudis, P.D.; Harrel, S.L. Release of the Digital Unified Global Geologic Map of the Moon At 1:5,000,000-Scale. In Proceedings of the 51st Lunar and Planetary Science Conference, Houston, TX, USA, 16-20 March 2020.

50. Pinto, L.; Fortunato, A.B.; Freire, P. Sensitivity analysis of non-cohesive sediment transport formulae. Cont. Shelf Res. 2006, 26, 1826-1839. [CrossRef]

51. Denghua, Z.; Jie, L.; Mingchao, L. An approach to 3D NURBS modelling of complex fault network considering its historic tectonics. Prog. Nat. Sci. 2006, 16, 546-553. [CrossRef]

52. Pinto, V.; Font, X.; Salgot, M.; Tapias, J.C.; Mana, T. Using 3-D structures and their virtual representation as a tool for restoring opencast mines and quarries. Eng. Geol. 2002, 63, 121-129. [CrossRef]

53. Lemon, A.M.; Jones, N.L. Building solid models from boreholes and user-defined cross-sections. Comput. Geosci. 2003, $29,547-555$. [CrossRef]

54. Turner, A.K. Applications of three-dimensional geoscientific mapping and modeling systems to hydrogeological studies. In Three-Dimensional Modeling with Geoscientific Information Systems; Springer: Dordrecht, The Netherlands, 1992; pp. 327-364. [CrossRef]

55. Apel, M. From 3d geomodelling systems towards 3d geoscience information systems: Data model, query functionality, and data management. Comput. Geosci. 2006, 32, 222-229. [CrossRef]

56. Baojun, W.; Bin, S.; Zhen, S. A simple approach to 3D geological modelling and visualization. Bull. Eng. Geol. Environ. 2009, 68, 559-565. [CrossRef]

57. Wilhelms, D.E.; Byrne, C.J. Stratigraphy of Lunar Craters. Available online: http://www.imageagain.com/Strata/ StratigraphyCraters (accessed on 15 October 2021).

58. Crater Analysis Techniques Working Group. Standard techniques for presentation and analysis of crater size-frequency data. Icarus 1979, 37, 467-474. [CrossRef]

59. Neukum, G.; Ivanov, B.A. Crater size distributions and impact probabilities on Earth from Lunar, terrestrial-planet, and asteroid cratering data. In Hazards Due to Comets and Asteroids; Gehrels, T., Ed.; University of Arizona Press: Tucson, AZ, USA, 1994; pp. 359-416.

60. Neukum, G.; Ivanov, B.A.; Hartmann, W.K. Cratering Records in the Inner Solar System in Relation to the Lunar Reference System, Chronology and Evolution of Mars. In Space Sciences Series of ISSI; Kallenbach, R., Geiss, J., Hartmann, W.K., Eds.; Springer: Dordrecht, The Netherlands, 2001; pp. 55-86. [CrossRef]

61. Kneissl, T.; van Gasselt, S.; Neukum, G. Map-projection-independent crater size-frequency determination in GIS environmentsNew software tool for ArcGIS. Planet. Space Sci. 2011, 59, 1243-1254. [CrossRef] 
62. Mustard, J.F.; Pieters, C.M.; Isaacson, P.J.; Head, J.W.; Besse, S.; Clark, R.N.; Klima, R.L.; Petro, N.E.; Staid, M.I.; Sunshine, J.M.; et al. Compositional diversity and geologic insights of the Aristarchus crater from Moon Mineralogy Mapper data. J. Geophys. Res. Planets 2011, 116, 1-17. [CrossRef]

63. Cheek, L.C.; Pieters, C.M.; Boardman, J.W.; Clark, R.N.; Combe, J.P.; Head, J.W.; Isaacson, P.J.; McCord, T.B.; Moriarty, D.; Nettles, J.W.; et al. Goldschmidt crater and the Moon's north polar region: Results from the Moon Mineralogy Mapper (M3). J. Geophys. Res. Planets 2011, 116. [CrossRef]

64. Varatharajan, I.; Srivastava, N.; Murty, S.V. Mineralogy of young lunar mare basalts: Assessment of temporal and spatial heterogeneity using M3 data from Chandrayaan-1. Icarus 2014, 236, 56-71. [CrossRef]

65. Kumaresan, P.R.; Saravanavel, J.; Palanivel, K. Lithological mapping of Eratosthenes crater region using Moon Mineralogy Mapper of Chandrayaan-1. Planet. Space Sci. 2020, 182, 104817. [CrossRef]

66. Arivazhagan, S.; Karthi, A. Compositional and chronological characterization of mare crisium using Chandrayaan-1 and LROC-WAC data. Planet. Space Sci. 2018, 161, 41-56. [CrossRef]

67. Karthi, A.; Arivazhagan, S. Chronological and compositional mapping of the Mare Orientale basin using Chandrayaan-1-M3 and LRO datasets. Icarus 2021, 10, 114844. [CrossRef]

68. Pieters, C.M.; Hanna, K.D.; Cheek, L.; Dhingra, D.; Prissel, T.; Jackson, C.; Moriarty, D.; Parman, S.; Taylor, L.A. The distribution of Mg-spinel across the Moon and constraints on crustal origin. Am. Mineral. 2014, 99, 1893-1910. [CrossRef]

69. Chauhan, M.; Bhattacharya, S.; Pathak, S.; Chauhan, P. Remote spectral-compositional analysis of basalt mineralogy at HansteenBilly, Moon. Meteorit. Planet. Sci. 2018, 53, 2583-2595. [CrossRef]

70. Thesniya, P.M.; Rajesh, V.J.; Flahaut, J. Ages and chemistry of mare basaltic units in the Grimaldi basin on the nearside of the Moon: Implications for the volcanic history of the basin. Meteorit. Planet. Sci. 2020, 55, 2375-2403. [CrossRef]

71. Thesniya, P.M.; Rajesh, V.J. Pyroxene chemistry and crystallization history of basaltic units in the Mare Humorum on the nearside of the Moon: Implications for the volcanic history of the region. Planet. Space Sci. 2020, 193, 105093. [CrossRef]

72. Bhatt, H.; Chauhan, P.; Solanki, P. Compositional mapping and the evolutionary history of Mare Tranquillitatis. J. Earth Syst. Sci. 2020, 129, 1-4. [CrossRef]

73. Clark, R.N.; Roush, T.L. Reflectance spectroscopy: Quantitative analysis techniques for remote sensing applications. J. Geophys. Res. Solid Earth 1984, 89, 6329-6340. [CrossRef]

74. Pieters, C.M.; Taylor, L.A.; Noble, S.K.; Keller, L.P.; Hapke, B.; Morris, R.V.; Allen, C.C.; McKAY, D.S.; Wentworth, S. Space weathering on airless bodies: Resolving a mystery with lunar samples. Meteorit. Planet. Sci. 2000, 35, 1101-1107. [CrossRef]

75. Hapke, B. Space weathering from Mercury to the asteroid belt. J. Geophys. Res. Planets 2001, 106, 10039-10073. [CrossRef]

76. Lucey, P.G.; Taylor, G.J.; Malaret, E. Abundance and distribution of iron on the Moon. Science 1995, 268, 1150-1153. [CrossRef] [PubMed]

77. Wilcox, B.B.; Lucey, P.G.; Gillis, J.J. Mapping iron in the lunar mare: An improved approach. J. Geophys. Res. Planets 2005, 110. [CrossRef]

78. Cloutis, E.A.; Gaffey, M.J. Pyroxene spectroscopy revisited: Spectral-compositional correlations and relationship to geothermometry. J. Geophys. Res. Planets 1991, 96, 22809-22826. [CrossRef]

79. Cloutis, E.A.; Gaffey, M.J. Spectral-compositional variations in the constituent minerals of mafic and ultramafic assemblages and remote sensing implications. Earth Moon Planets 1991, 53, 11-53. [CrossRef]

80. Klima, R.L.; Pieters, C.M.; Boardman, J.W.; Green, R.O.; Head, J.W.; Isaacson, P.J.; Mustard, J.F.; Nettles, J.W.; Petro, N.E.; Staid, M.I.; et al. New insights into lunar petrology: Distribution and composition of prominent low-Ca pyroxene exposures as observed by the Moon Mineralogy Mapper (M3). J. Geophys. Res. Planets 2011, 116. [CrossRef]

81. Horgan, B.H.; Cloutis, E.A.; Mann, P.; Bell, J.F., III. Near-infrared spectra of ferrous mineral mixtures and methods for their identification in planetary surface spectra. Icarus 2014, 234, 132-154. [CrossRef]

82. Milton, D.J.; Barlow, B.C.; Brett, R.; Brown, A.R.; Glikson, A.Y.; Manwaring, E.A.; Moss, F.J.; Sedmik, E.C.; van Son, J.; Young, G.A Gosses bluff impact structure, Australia. Science 1972, 175, 1199-1207. [CrossRef]

83. Alexopoulos, J.S.; McKinnon, W.B. Large Impact Craters and Basins on Venus, with Implications for Ring Mechanics on the Terrestrial Planets; Special Papers-Geological Society of America: Boulder, CO, USA, 1994; p. 29.

84. Baker, D.M.; Head, J.W.; Fassett, C.I.; Kadish, S.J.; Smith, D.E.; Zuber, M.T.; Neumann, G.A. The transition from complex crater to peak-ring basin on the Moon: New observations from the Lunar Orbiter Laser Altimeter (LOLA) instrument. Icarus 2011, 214, 377-393. [CrossRef]

85. McCauley, J.F.; Wilhelms, D.E. Geological provinces of the near side of the Moon. Icarus 1971, 15, 363-367. [CrossRef]

86. Wilhelms, D.E.; McCauley, J.F. Geologic Map of the Near Side of the Moon; US Geological Survey: Washington DC, WA, USA, 1971

87. Wilhelms, D.E.; Oberbeck, V.R.; Aggarwal, H.R. Size-frequency distributions of primary and secondary lunar impact craters. In Proceedings of the 9th Lunar and Planetary Science Conference, Houston, TX, USA, 13-17 March 1978; pp. 3735-3762.

88. Golombek, M.P. Structural analysis of lunar grabens and the shallow crustal structure of the Moon. J. Geophys. Res. Solid Earth 1979, 84, 4657-4666. [CrossRef]

89. Watters, T.R.; Johnson, C.L.; Schultz, R.A. Lunar tectonics. Planet. Tecton. 2010, 11, 121-182.

90. Klimczak, C. Geomorphology of lunar grabens requires igneous dikes at depth. Geology 2014, 42, 963-966. [CrossRef]

91. Nahm, A. Spatial Distribution and Characteristics of Graben on the Lunar Nearside. In Proceedings of the EGU General Assembly Conference Abstracts, Vienna, Austria, 17-22 April 2016. 
92. Jozwiak, L.M.; Head, J.W.; Wilson, L. Lunar floor-fractured craters as magmatic intrusions: Geometry, modes of emplacement, associated tectonic and volcanic features, and implications for gravity anomalies. Icarus 2015, 248, 424-447. [CrossRef]

93. Burg, J.P. 2014 Brittle Faulting. Available online: https://www.Bles.ethz.ch/structuralgeology/JPB/Bles/English/2faulting.pdf (accessed on 25 September 2021).

94. Odling, N.E. Fluid Cow in fractured rocks at shallow levels in the Earth's crust: An overview. In Deformation Enhanced Fluid Transport in the Earth's Crust and Mantle; Holness, M.B., Ed.; Chapman and Hall: London, UK, 1997; pp. $289-314$.

95. Hargitai, H.; Byrne, P.K.; Korteniemi, J. Fracture. In Encyclopedia of Planetary Landforms; Hargitai, H., Kereszturi, A., Eds.; Springer: Berlin/Heidelberg, Germany, 2015; pp. 794-801.

96. Morgan, J.; Bray, V.J. Peak-Ring Structure. In Encyclopedia of Planetary Landforms; Springer: Berlin/Heidelberg, Germany, 2014; pp. 1-8. [CrossRef]

97. Baldwin, R.B. On the tsunami theory of the origin of multi-ring basins. In Multi-Ring Basins: Formation and Evolution; Pergamon Press: New York, NY, USA, 1981; pp. 275-288.

98. Melosh, H.J. A schematic model of crater modification by gravity. J. Geophys. Res. Solid Earth 1982, 87, 371-380. [CrossRef]

99. Morgan, J.V.; Warner, M.R.; Collins, G.S.; Grieve, R.A.; Christeson, G.L.; Gulick, S.P.; Barton, P.J. Full waveform tomographic images of the peak ring at the Chicxulub impact crater. J. Geophys. Res. Solid Earth 2011, 116, 1-16. [CrossRef]

100. Hurwitz, D.M.; Head, J.W.; Hiesinger, H. Lunar sinuous rilles: Distribution, characteristics, and implications for their origin Planet. Space Sci. 2013, 79, 1-38. [CrossRef]

101. Spudis, P.D.; Swann, G.A.; Greeley, R. The formation of Hadley Rille and implications for the geology of the Apollo 15 region. In Proceedings of the 19th Lunar and Planetary Science Conference, Houston TX, USA, 14-18 March 1988; pp. $243-254$.

102. Head, J.W.; Wilson, L. Lunar sinuous rille formation by thermal erosion: Conditions, rates and durations. In Proceedings of the 12th Lunar and Planetary Science Conference, Houston, TX, USA, 16-20 March 1981; pp. 427-429.

103. Hurwitz, D.M.; Head, J.W.; Wilson, L.; Hiesinger, H. Origin of lunar sinuous rilles: Modeling effects of gravity, surface slope, and lava composition on erosion rates during the formation of Rima Prinz. J. Geophys. Res. Planets 2012, 117, E00H14. [CrossRef]

104. Losiak, A.; Wilhelms, D.E.; Byrne, C.J.; Thaisen, K.G.; Weider, S.Z.; Kohout, T.; O'Sullivan, K.; Kring, D.A. A new lunar impact crater database. In Proceedings of the 40th Lunar and Planetary Science Conference, Houston, TX, USA, 23-27 March 2009; p. 1532.

105. Losiak, A. A new lunar impact crater database (updated). In Proceedings of the 46th Lunar and Planetary Science Conference, Houston, TX, USA, 16-20 March 2015.

106. Lucchitta, B.K.; Watkins, J.A. Age of graben systems on the Moon. In Proceedings of the 9th Lunar and Planetary Science Conference, Houston, TX, USA, 13-17 March 1978; pp. 3459-3472.

107. Watters, T.R.; Robinson, M.S.; Banks, M.E.; Tran, T.; Denevi, B.W. Recent extensional tectonics on the Moon revealed by the Lunar Reconnaissance Orbiter Camera. Nat. Geosci. 2012, 5, 181-185. [CrossRef]

108. Trask, N.J. Geologic comparison of mare materials in the lunar equatorial belt, including Apollo 11 and Apollo 12 landing sites. US Geol. Surv. Prof. Pap. 1971, 750D, 138-148.

109. French, R.A.; Bina, C.R.; Robinson, M.S.; Watters, T.R. Small-scale lunar graben: Distribution, dimensions, and formation processes. Icarus 2015, 252, 95-106. [CrossRef]

110. Pieters, C.M.; Hiroi, T. RELAB (Reflectance Experiment Laboratory): A NASA multiuser spectroscopy facility. In Proceedings of the 35th Lunar and Planetary Science Conference, Houston, TX, USA, 15-19 March 2004; p. 1720. Available online: https: / / www.planetary.brown.edu/relab. (accessed on 23 October 2021).

111. Gaffey, M.J.; Cloutis, E.A.; Kelley, M.S.; Reed, K.L. Mineralogy of asteroids. In Asteroids III; Bottke, W.F., Cellino, A., Paolicchi, P., Binzel, R.P., Eds.; University of Arizona Press: Tucson, AR, USA, 2002; pp. 183-204.

112. Horgan, B.; Bell, J.F., III. Widespread weathered glass on the surface of Mars. Geology 2012, 40, 391-394. [CrossRef]

113. Xiao, L.; Head, J.W. Geological Characteristics of the Moon. In Oxford Research Encyclopedia of Planetary Science; Oxford University Press: Oxford, UK, 2020. [CrossRef]

114. Pieters, C.M. Bullialdus: Strengthening the case for lunar plutons. Geophys. Res. Lett. 1991, 18, 2129-2132. [CrossRef]

115. Tompkins, S.; Pieters, C.M. Mineralogy of the lunar crust: Results from Clementine. Meteorit. Planet. Sci. $1999,34,25-41$. [CrossRef] 